\title{
Countering Educational Disparities Among Black Boys and Black Adolescent Boys from Pre-K to High School: A Life Course-Intersectional Perspective
}

\author{
Keisha M. Wint ${ }^{1}$ D $\cdot$ Ijeoma Opara $^{2} \cdot$ Rahjaun Gordon $^{1} \cdot$ Derrick R. Brooms $^{3}$
}

Accepted: 23 August 2021 / Published online: 20 September 2021

(c) The Author(s), under exclusive licence to Springer Nature B.V. 2021

\begin{abstract}
Accounts of educational opportunity gaps for Black boys are overwhelmingly focused on later years of development. Achievement and discipline disparities are evident across their lifespan. Life course and intersectionality theories were used to develop a framework for understanding obstacles Black boys face during their preschool through high school years. Outlining the cumulative impact of threats and protective factors for their academic success provides insight for supporting Black boys at various developmental stages. Implications include tools for families, educators, and practitioners. This perspective will enhance the collective understanding of the resiliency of Black boys and support their educational success throughout the life course.
\end{abstract}

Keywords Black boys · Black adolescent boys · Education · Life course · Intersectionality $\cdot$ Development $\cdot$ Well-being

Educational research in the United States often ignores the resilience and strengths of Black boys and men. For decades, researchers and public discourse have focused on viewing Black boys from a deficit perspective, highlighting the myriad of ways they have been negatively impacted by systemic factors within the educational system (Carey, 2020; Goff et al., 2014; Howard, 2013; Noguera, 2003). Achievement outcomes for Black males have predominantly been measured during adolescent and adult years; these outcomes negate the crucial early years of development (Davis,

Keisha M. Wint

KeishaWint.phd@gmail.com

1 Department of Family Science and Human Development, Montclair State University, Montclair, USA

2 Department of Social and Behavioral Sciences, School of Public Health, Yale University, New Haven, USA

3 Department of Sociology and Africana Studies, University of Tennessee, Knoxville, USA 
2003; Dumas \& Nelson, 2016; Wright \& Counsell, 2018). The research community has given little attention to the connection between early learning years and the adverse experiences and treatment of Black boys and Black adolescent boys during their later educational years (Gaylord-Harden et al., 2018). Discussions centered on Black boys and Black adolescent boys often fail to contextualize the complexity of their experiences over time (Swanson et al., 2003) which further reifies inaccurate negative assumptions of Black boys and Black adolescent boys. Failure to acknowledge the dynamic and cumulative nature of their experiences relegates those who engage with and educate Black boys and Black adolescent boys to provide maladjusted support; thus, neglecting their specific developmental experiences and needs within the educational context. Additional research is warranted to examine how the cumulative effect of early school engagement may impact the overall educational attainment of Black males as a group (Rowley et al., 2014). Given the obstacles experienced by Black boys and men across the educational continuum, research must now focus on reframing their developmental experience, understanding the keys to their resilience, and creating innovative, strengths-based approaches for improving educational outcomes.

The central aim of this conceptual manuscript is to contextualize the educational experiences of Black boys across developmental time within the educational system. Acknowledging how the intersections of race and gender continue to threaten the success of Black males beginning in preschool and extending into high school requires an awareness of their strengths and resilience throughout the life course. This posture calls for researchers and practitioners to simultaneously question the predominant deficit-based narratives that persists within $U$. S. society. Throughout this text, we appropriately refer to Black males as "boys" during the preschool through elementary years, "Black adolescent boys" during middle and high school years. This distinction is used to highlight their nurture-dependent stages of development and contextualize their age specific developmental needs (Carey, 2020; Dumas \& Nelson, 2016). In so doing, we draw attention to the brilliance, strengths, and possibilities of Black boys and Black adolescent boys as they journey from preschool to high school.

We begin by sharing our researchers' positionalities and follow by describing our conceptual framework (see Fig. 1) and its theoretical underpinnings. Next, we highlight the possibilities and potential of Black boys and Black adolescent boys through our discussion of protective factors. Finally, we outline the specific developmental experiences Black boys may have in school. At the end of each educational stage, we present information regarding reparative practices educational professionals may implement at each stage to support Black boys. Ultimately, we present our comprehensive conceptual framework to guide researchers, educators, and clinicians in conducting a critical examination of challenges Black boys and Black adolescent boys may experience. This perspective further informs strengths-based approaches to working with and for Black boys and Black adolescent boys across various developmental stages. 

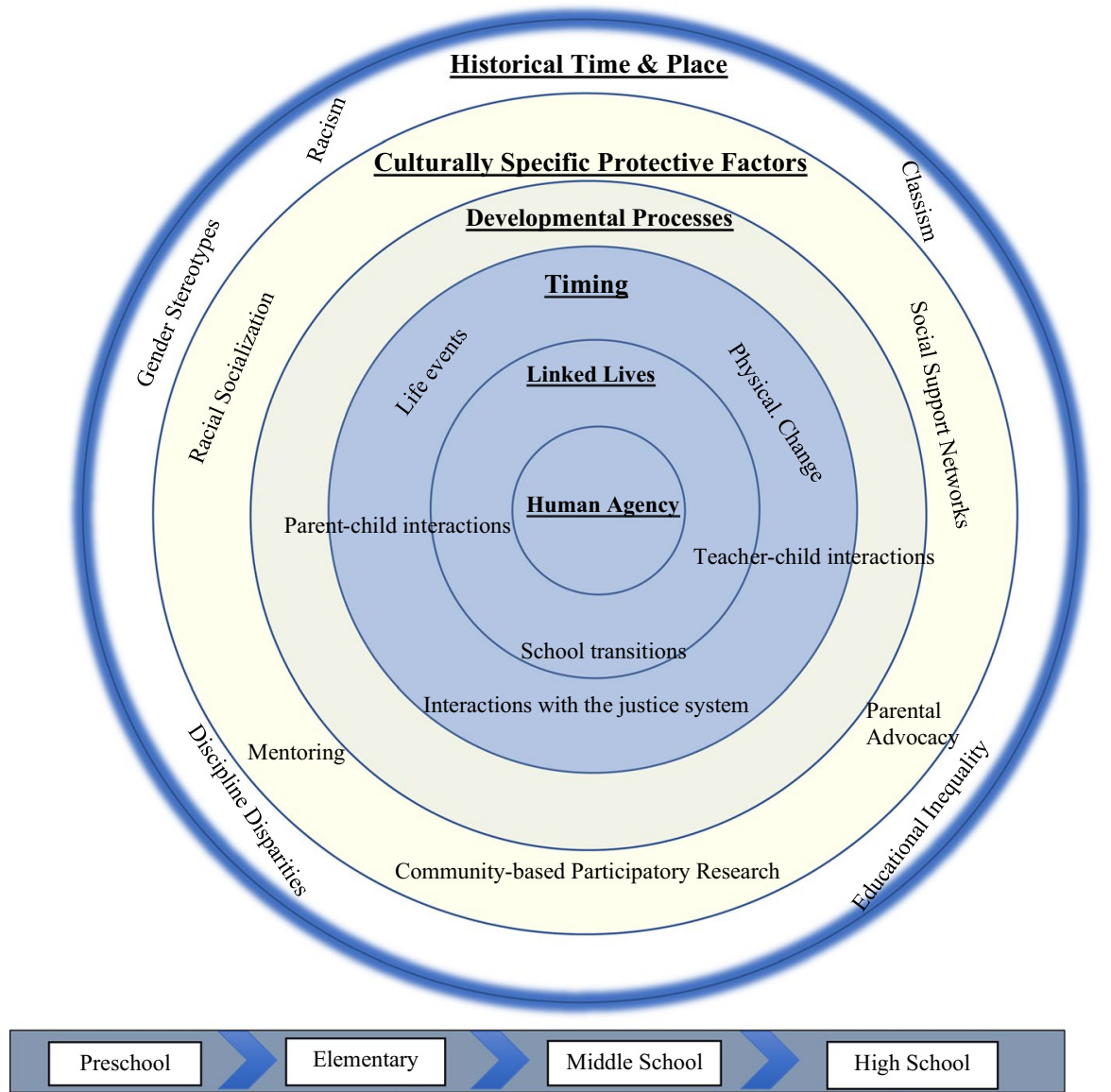

Fig. 1 Illustration of a Model for Understanding the Life Course of Black Boys and Black Adolescent Boys in Education through an Intersectional Lens. Note. The model depicts life course principles in relation to intersectional factors which influence Black boys and Black adolescent boys in education. The principles show progression of macro-level considerations at outer circles and shift towards micro-level considerations at the inner parts. The second layer highlights the protective factors. The horizontal movement reflects the temporal progress across various educational stages

\section{Researchers' Positionalities}

The authors of this paper co-labor with and for Black children, men, and women across the educational continuum and share a collective commitment to and investment in the lives of Black people. Specifically, the first author identifies as a Black female and is a licensed clinical social worker who serves as a coach for preschool educators in an urban district. She collaborates with families in private practice and engages in research and scholarship with Black preschool boys centered on their relational experiences with teachers. The second author identifies as a Black female and currently works as faculty member in a large university and a licensed social 
worker. She facilitates community-engaged research with Black youth using intersectionality as a foundational theory to highlight their strengths and acknowledge their intersecting identities in her research and practice. The third author identifies as a Black male and is a program director for a leadership program that serves Black and Latinx students at a state university. He participates in research and scholarship related to leadership development and mentoring relationships of first-generation Black male college students. The fourth author identifies as a Black male and currently serves as a faculty member, researcher, and youth worker. Along with curating a research profile deeply invested in their lives, he has developed, facilitated, and continues to contribute to school- and community-based programs centered on Black boys and men at both the secondary and postsecondary levels, and serves as a coach and mentor, both formally and informally. Given this collective range of experiences and advocacy for and with Black children and families, the authors of this paper utilized the existing literature related to the realities of Black boys and men and their personal experiences, during various developmental stages to counter the prevalent myths and misperceptions of Black boys and Black adolescent boys.

\section{Conceptual Framework: Life Course Theory-Intersectionality for Black Boys and Black Adolescent Boys}

The Contextualized Life Course-Intersectional Framework [CLCIF] (see Fig. 1) highlights the principles of life course theory which include historical time and place, developmental processes, timing, linked lives, and human agency (Elder, 1998). These principles are boldly centered within each layer of the framework across five concentric circles. The outermost layer illustrates a range of macro level systems and oppressive structures Black boys and Black adolescent boys have and continue to experience throughout American history given their social location. This denotes the acknowledgement of how history and oppressive educational barriers such as racism, classism, and gender stereotypes have colored the experiences of Black boys in education and rejects the idea of a unilateral or static perspective for understanding experiences. As such, the framework also incorporates a buffering layer of culturally specific protective factors including racial socialization which may serve as tools for advancing the educational success of Black boys (Edwards \& Few-Demo, 2016). Each consecutive inner circle reflects a progressive shift towards micro-level considerations such as relational influences, individual choice, and agentic action. This inward shift towards human agency presents increased opportunities for micro-level change both within educational settings and the lived educational experiences of Black boys. This shift highlights the importance of relational connections and individual choice as viable opportunities for positive change when culturally specific protective tools/ skills are activated and utilized.

Taken together, CLCIF posits an awareness of dynamic and interwoven connection amongst context, time, processes, relationships, and agency to influence educational possibilities for Black boys. The framework underscores the complexities of various factors and suggests supports for Black boys must be developed across the lifespan and intentionally consider developmental processes, timing, relationships, 
and individual choice. The horizontal movement across the educational trajectory from preschool to high school, reflects an awareness that each factor has the protentional to have a cumulative influence on the educational experiences as Black boys move across each educational stage.

Our conceptual framework was informed using two theories: Life Course Theory (Elder, 1998) and Intersectionality Theory (Crenshaw, 1991; Collins, 2000). Life course theory provides a temporal lens through which to explore the experiences of Black boys and Black adolescent boys in education. It examines how individuals at various stages of development are shaped by the events in their lives and posits the life of an individual must be understood in context (Elder, 1998). Complimentarily, intersectionality theory accounts for the sociohistorical experiences of Black males as a group and acknowledges the systemic and structural barriers that have placed Black boys, men, and their families at risk. Intersectionality theory further contends the intersecting identities to which Black boys and Black adolescent boys belong do not operate in silos but simultaneously (Nelson et al., 2015), which contributes to the challenges that manifest throughout their educational life course (Collins, 2000). As illustrated in the framework (see Fig. 1) both life course and intersectionality theories collectively acknowledge the occurrence of racially gendered experiences that ensue during critical grade levels such as preschool, middle school, and high school. These experiences impact overall school engagement for Black boys over time (Nelson et al., 2015; Toldson et al., 2006).

\section{Life Course Theory}

Five central principles of life course theory include (a) historical time and place, (b) developmental processes, (c) timing, (e) linked lives, and (d) human agency (Elder, 1998). These principles underscore the importance of time, context, relationships, and processes (Elder, 1998; Elder \& Shanahan, 2006). Beginning with the outer circles, Historical time and place underscore how groups and cohorts are shaped by their experiences over time (Elder, 1998). For example, cohorts who came of age during the Great Depression in the 1930s or during the COVID-19 era of the 2020's have distinct experiences marked by the sociocultural context during those periods in history. Historically, Black males as a group have been negatively shaped by their experiences within the society and the educational system for generations due to racism and gendered stereotypes (Dumas \& Nelson, 2016; Noguera, 2003; Rashid, 2009). The murder of a Black father - George Floyd — at the hands of a White police officer garnered international attention regarding the threats Black men experience in society (Dreyer et al., 2020). Within the school context, oppressive acts committed against Black children such as excessive suspensions and school discipline disparity influence how Black boys view themselves in relation to society (Okonofua et al., 2016). The unique sociohistorical context Black boys experience in education due to policies both in and out of school (Jenkins, 2006; Noguera, 2003) points to a critical need for researchers to contextually explore their educational experiences starting during the early learning years. 
Developmental processes highlight the sequence to life events and how earlier life decisions may influence later outcomes. As such, development is seen as an interchange between an evolving social world, adjustments in context, and changes in the individual over time (Elder, 1998). The connections between childhood, adolescence, and later adult experiences are evident in this principle and support the need for a cumulative accounting of the experiences of Black boys as they transition to each subsequent grade in the educational context. Human development is also social and is illustrated as individuals who attain critical ages (i.e., 5 and 18) in society and simultaneously acquire educational and legal status. Contrastingly for Black boys, the social nature of their educational experiences reflects increased unjust treatment of being feared and policed as they mature physically (Bryan, 2017; Carey, 2020; Howard, 2013; Skiba et al., 2014). Both the social and cumulative natures of development suggest their educational experiences in one developmental stage has the potential to influence subsequent schooling experiences (Elder, 1998).

The principle of linked lives identifies the ways individuals are influenced through their connections with significant others in their lives (Elder, 1998). The teacher-child relationship provides a relevant example of how a child's life can be positively linked with those outside the family (Brenner, 2011). These linked or interconnected lives in the early educational environment also have the potential to influence the success with which children thrive or are inhibited across the educational continuum (Brenner, 2011; Johnson et al., 2001). The principle of linked lives also illustrates the significance of social networks as connections, which have the potential to improve outcomes for Black boys (Leonard, 2011; Lucas, 2018).

Timing emphasizes the notion events may impact individuals differently based on the developmental stage of the individual when the event occurs (Elder, 1998). Similarly, the first and introductory transition into the educational system for young Black boys (i.e., at 3 or 4 years of age) has potential implications for shaping and molding his social-emotional development, self-identity, and overall school adjustment (National Black Child Development Institute [NBCDI], 2015; National Institute for Early Education Research [NIEER], 2015; Pungello et al., 2010). During this early and critical stage of development, the principle of timing points to an increased need to protect and safeguard their vulnerability.

Human agency refers to an individual's choices, decisions, or plans that alter or shape their path (Elder, 1998) and is placed in the center of the CLCIF (see Fig. 1) model as the core of the framework. An example of agency might be reflected in the decision of a young boy to join a debate team or the football team. These distinct choices result in unique outcomes, which in turn may shape or alter his experience of school, the types of relationships he develops, and with whom. Human agency acknowledges various paths to an individual's life trajectory. Although life course theory presents a useful framework for examining the influence of historical time, societal shifts, developmental processes, and relationships on the experiences of Black boys and Black adolescent boys within the educational system, our discussion requires a deeper exploration of the ways race and gender intersect to inform their educational realities. 


\section{Intersectionality Theory}

Gender inequities have resulted in educational vulnerabilities for Black boys across all stages of development (Davis, 2003; Howard, 2013; Thomas \& Stevenson, 2009). Black boys' identities are distinctly racialized, gendered, and classed across different sociocultural and historical contexts (Curry, 2017; Mutua, 2006; Nelson et al., 2015); therefore, acknowledging such intersections is crucial in educational research. Researchers often study Black boys identities as separate social categories (e.g., race only) which discounts their identity processes. Rooted in feminist and critical race theories, intersectionality theory emerged from the need to discuss interlocking identities of race, class, and gender; and validate the lived experiences of Black women, which did not fit into a single categorical axis (Crenshaw, 1991). Intersectionality theory is used to examine the multiple dimensions of identities, social locations, and how these two constructs intersect (Collins, 2000). Throughout educational research, theorists have utilized critical race theory (Delgado, 2005) to argue the plight of Black males in educational systems due to their race and social position in society (Nelson et al., 2015; Rogers et al., 2015). This approach allows researchers to examine power, privilege, and oppression in society within the context of race. Intersectionality theory aids in understanding race, gender, and class are not reducible to individual attributes, but form a mutually constituted system of relationships (Collins, 2000; Veenstra, 2011). While Crenshaw's (1989, 1991) articulation of intersectionality focused primarily on Black women and their intersecting systems of inequality and oppressions, researchers have established that Black boys also experience multiple forms of marginalization due to their social identities which are not mutually exclusive. Therefore, we utilize Collins' (2000) framework of intersectionality theory which poses that gender is often filtered through the lens of race which contributes to how individuals are treated. Applying Collins' (2000) approach allows for a comprehensive application of Black boys whose identities are not viewed separately as "Black" and "male" but as "Black males" which calls upon and depends on negative stereotypes and deficit framings (e.g., Black boy as threat) by society that affect their outcomes.

As researchers begin to explore the role of intersectionality and examine the interconnectedness of race, gender, and class in the lives of Black males, they enhance the potential to learn about the barriers that continue to place Black boys and Black adolescent boys at risk of negative educational outcomes. Within educational research, there are few examples of intersectionality theory applied to Black boys' schooling experiences (McCready, 2010; Rogers et al., 2015; Wright et al., 2016). As an example, using intersectionality to inform their study of identity development among Black adolescent males, while acknowledging that identities are mutually constitutive, Rogers et al. (2015) contended race is filtered through the lens of gender "such that the social identity of 'Black male' becomes the unit of investigation rather than the separate identities of 'Black' and 'male", (p. 409). They found the development and intersections of racial and gender identities during mid-adolescence 'are 'under construction,' they are influx, both 
supporting and, at times, counteracting each other" (p. 419). Thus, this research and others support the focus of our work and conceptualization of our CLCIF.

Beyond educational research, some scholars have argued for focused research to account for the intersecting race-gender realities of Black males (e.g., Curry, 2017; Mutua, 2006). For instance, in theorizing Black manhood and masculinity, Curry (2017) called for a genre study of Black malehood, coined as Black male studies, which focused on Black boys and men at the axis of history, sociology, and philosophy. Relatedly, Mutua's (2006) work on Black maleness has proved noteworthy and calls for greater specificity of gendered racism experienced by Black boys and men. As illustrated in the outer layers of the CLCIF (see Fig. 1), we acknowledge these works and the need to interrogate how Black boys' and Black adolescent boys' intersecting identities matter in their lived experiences. We see our approach aligned with these contributions as we incorporate the collective influence of racism, gendered stereotypes, classism, and educational inequity on the educational experience of Black boys and Black adolescent boys. Intersectionality is particularly useful for our work as it provides a frame to understand Black boys (and men) as whole beings. The use of intersectionality theory within a life-course perspective calls attention to multiple social identities of Black boys and Black adolescent boys as they move across the educational trajectory. This perspective considers the ways these social identities matter in their lived experiences, accounts for their strengths and assets.

\section{Guarding the Promise and Possibilities of Black Boys and Black Adolescent Boys through Culturally Specific Protective Factors}

Within the CLCIF, we incorporated protective factors (racial socialization, social support and mentoring relationships, and community-engaged work) necessary to change the deficit narrative of Black boys while highlighting their strengths and resilience. In addition to other anti-deficit achievement frameworks which explore how Black male students navigate, persist, and thrive in education (Harper, 2010), we explore protective factors as vital components to first acknowledge and subsequently use to help dismantle the impact of oppressive systems and the perpetuation of negative and uninformed narratives about Black boys and Black adolescent boys. The support systems within which Black boys and Black adolescent boys are proximally and distally nested highlight important factors for their educational success (Bronfenbrenner \& Morris, 2006; Carey, 2020; Nelson, 2016). Consequently, being embedded in nurturing, environments which instill confidence in their academic potential is empowering and critical for the support of their health and well-being (Brooms, 2019; Fergus et al., 2014; Grey, 2018). As such, the narratives we believe in fact inform the way Black boys and Black adolescent boys live out their lives.

The use of culturally specific protective factors outlined in this section are inspired by intersectionality concepts and attend to the developmental needs of Black boys and Black adolescent boys. Such factors serve as buffers to aid in their success and incorporate elements of our analysis of their experiences across the educational continuum. The role of family, nurturing relationships, and strong social supports have been highlighted as key protective factors for Black male success in education across 
all stages of development (Brooms, 2019; Brown et al., 2013; Dumas \& Nelson, 2016; Iruka et al., 2015, Nelson, 2016). Research has also espoused involvement in organizational activities and programmatic initiatives, that focus race and gender as relevant support systems proven to enhance the academic achievement of Black boys and Black adolescent boys (Martin, 2007; Nelson, 2016; Patton et al., 2011). The discussion to follow highlights the role of racial socialization, social supports, and mentoring relationships, as well as the need for community engaged research efforts. These protective factors simultaneously provide increased awareness of the unique individual experiences of Black boys and Black adolescent boys while celebrating their resilience, promise, and potential through intentional efforts to create equitable and affirming experiences across the educational landscape.

\section{Racial Socialization}

Given the cumulative nature of oppressive systems (Collins, 2000; Crenshaw, 1991), age-and race-specific interventions can be useful in improving outcomes for Black boys. Social supports aimed at developing the skill and esteem of Black boys and Black adolescent boys may be continuously and incrementally warranted throughout each developmental stage (Harper et al., 2009). One aspect of racial socialization speaks to familial practices which prepare Black children to navigate discrimination and racism as well as enhance their knowledge of Black history and culture (Edwards \& Few-Demo, 2016; Howard et al., 2013). An awareness of Black history and culture is critical at every stage of development for Black children as this kind of education may not be consistently provided in schools. Part of the socialization and reeducation for all children requires ongoing knowledge of the past and current scholarship and contributions of Black people within and across various fields science, education, and the arts. Beginning in early childhood, instruction focused on helping families develop their capacity to provide all children with ongoing counter narratives through books, educational curricula, and other affirming media is vital. At the earliest stage of development, such illustrations may be reflected in books like Full, Full, Full of Love (Cooke, 2008) or Little Legends: Exceptional Men in Black History (Harrison, 2019). This knowledge will serve Black children well in recapturing and reclaiming the history and collective legacy of brilliance and skill in the United States and around the globe.

\section{Social Supports and Mentoring Relationships}

The contexts within which Black boys and Black adolescent boys are developing (i.e., society, neighborhoods, schools, and families) highlight important factors for their educational success (Bronfenbrenner \& Morris, 2006; Carey, 2020; Nelson, 2016). As such, restructuring such environments to create more equitable opportunities as well as foster confidence and equipping Black boys and Black adolescent boys to make agentic decisions towards achieving their academic potential is critical (Brooms, 2019; Fergus et al., 2014; Grey, 2018). These support systems include educators (i.e., teachers, counselors), mentors, community members, and the family. 
The familial role has been highlighted as an important protective factor supporting the success of Black youth in school (Brown et al., 2008). Research has shown Black males have an increased likelihood of graduating high school when a parent or guardian supports their educational or career goals and when Black boys have exposure to role models who have secured economic success through academic achievement (Toldson et al., 2006). However, some reports also suggest parents of Black children have higher expectations for their daughters than their sons; parents also perceived their daughters to be more academically competent (Wood et al., 2011). These findings regarding familial views of competence underscore the quandaries some Black boys and Black adolescent boys may experience as they advance within the educational context and point to the importance of intersectionality to account for gendered inequalities even in families. As illustrated in the CLCIF (see Fig. 1), such realities further illustrate how family-child relationships may also be tainted by the insidious effects of indoctrination within systems which are influenced by and at times premised on racist ideologies (Hines \& Holcomb-McCoy, 2013; Mandara, 2006).

As Black boys and Black adolescent boys continue to negotiate challenges and obstacles they may encounter within the educational context, they will require qualified teachers who are equipped with cultural proficiency to support their development as critical thinkers (Fergus et al., 2014; Howard, 2001). This approach demands educators have high student expectations, provide rigorous academic challenges, and develop individual and culturally relevant approaches to learning; this must also be achieved while maintaining efforts to establish authentic trusting relationships through positive engagement with young Black boys and Black adolescent boys (Harper et al., 2009; Nelson, 2016).

To harness the proven power of mentoring relationships (Jackson et al., 2014) both in and out of the educational sector, communities and schools must work together to build support networks for Black boys and men. Relationships geared toward their educational success in school may potentially build social capital within industries boys and Black adolescent boys plan to pursue careers. This may provide students with tangible opportunities to believe in the benefits and rewards of education. These mentoring connections which can begin as early as prekindergarten, may create a supportive relational network to instill hope and motivation for young Black boys early in the educational trajectory. Community support and mobilization are essential for ensuring Black males are supported throughout the educational process from preschool to higher education.

\section{Community-Engaged Work}

Young Black boys who internalize misconceptions may become less likely to have a positive outlook on their own academic potential. Facilitating interactions that acknowledge rather than ignore the negative and at times demoralizing experiences Black boys and Black adolescent boys may have in school and society, provide brave and authentic spaces for Black boys and men to be heard, begin to heal, and continue to flourish (Brooms, 2017; Harper et al., 2009). In addition to supports which 
guard their social and emotional development, community-level campaigns are needed to highlight the importance of education for Black boys and Black adolescent boys. School-based campaigns must include representation of Black boys and males in positive roles (i.e. students, teachers, and school leaders) which are affirming to Black boys and men (Toliver, 2018). Representations of Black males who are succeeding across educational realms, particularly those who were able to thrive in under-resourced environments, may serve as a method of bolstering the antideficit narrative of educational attainment and success for Black males.

In addition to required supports across the life course, there is a need for developmentally specific instruction and guidance. Given both Black boys and Black adolescent boys are often victims of stereotypical notions that criminalize their behaviors (Bryan, 2021; Howard, 2013) they also face increased likelihood of being policed, violated, or killed (Dreyer et al., 2020). In addition to fighting for police reform laws, families must also advocate for formalized supports from community organizations to provide critical awareness, legal instruction, and guidance on how to navigate encounters with law enforcement. This kind of community-engaged support may provide Black boys and Black adolescent boys with knowledge and skill to stay alive both in and out of school.

\section{Contextualizing Experiences of Black Boys and Black Adolescent Boys across the Educational Trajectory using a Life Course-Intersectional Lens}

Life course theory emphasizes the interplay of social contexts over time in our understanding of human development (Elder, 1998). Anchoring the discussion of these principles through an intersectional lens provides a poignant understanding of challenges Black boys and Black adolescent boys may experience. Experiences may vary based on individual characteristics such as temperament, ability, and socioeconomic status (Garcia Coll et al., 1996). As such, the experiences of Black boys and Black adolescent boys should not be regarded as homogeneous (NBCDI, 2015). In this text, the preschool stage specifically relates to Black boys who are 3, 4, and 5 years of age and is subsequently followed by the elementary school experience. This stage reflects the experience of Black boys between the ages 6-11 years old. Finally, the middle and high school years reflect boys as they transition to adolescence starting at 12-17 years old. Special attention is given to the potential for cumulative effects of both challenges and resilience of both supportive and inhibiting environments (Garcia Coll et al., 1996) as well as the variation in context.

\section{Preschool}

The preschool experience serves as a foundation for current and future school success and has a significant impact on improving outcomes for children (Iruka et al., 2020; NIEER, 2015). Children who attend high-quality preschools have better 
health and cognitive outcomes and are less likely to use special education services or be retained (NIEER, 2015). Despite the many benefits of preschool, there are challenges inherent in being young and vulnerable. Namely, the developing language skills of younger children may make communication and misinterpretation of behavior more prevalent during this early stage (Wright \& Counsell, 2018). Preschool children are expelled at almost 4 times the rate of school-age children (U.S. Department of Education [DOE] Office for Civil Rights, 2014). Black children were expelled at twice the rate of non-Black preschoolers, and boys were expelled at 4.5 times the rate of girls (U.S. DOE Office for Civil Rights, 2014).

Experiencing harsh discipline practices during his first encounter with the educational system and may also make a lasting impression. Given Black preschool boys educated in state-funded programs are likely to be taught by teachers of a different race or ethnicity (Downer et al., 2016). This mismatch may result in teacher bias toward Black boys based on stereotypical views of their group (Bates \& Glick, 2013; Downer et al., 2016). Racial bias can result in harsher and more punitive disciplinary practices and can influence teachers' perceptions of a child's competence (Bates \& Glick, 2013; Gilliam et al., 2016). Young boys who experience excessive punishment or negative interactions from adults during their early learning years, may develop a lack of trust for adults in educational environments (Rashid, 2009). Preschool educators are tasked with negotiating the intersection of race, age, and gender as they develop relationships with very young Black boys. Early childhood educators must also acknowledge the specific sociocultural challenges and biases that exist for young Black boys, while simultaneously affirming the strengths of their multiple identities (Crenshaw, 1991).

\section{Building a Strong Foundation}

The preschool educator who sets the stage for success will usher Black boys to the start of their educational trajectory. A teacher's ability to fostering strong supportive relationships with families as a means of increasing attachment with young learners is an important factor in early educational success (Center on the Developing Child at Harvard University [CDCHU], 2015). As illustrated at the inner circles of CLCIF (see Fig. 1), the principles of timing and linked lives both illustrate how the introductory transition into the educational system for young Black boys at 3 or 4 years of age has potentially significant implications for shaping and molding social-emotional development and overall school adjustment (CDCHU, 2015; NIEER, 2015; Pungello et al., 2010). Early childhood educators must also be prepared to meet the unique developmentally appropriate needs of boys between ages 3 and 5. Typically, younger boys are inclined to be physically active and are likely to run, jump, and touch as ways of experiencing their environment (Morhard, 2013). The developmental needs of younger Black boys such as being active or engaging in play are policed very early in educational spaces. Younger Black boys are often not allowed the same luxuries to engage in developmentally appropriate play as other racial groups (Bryan, 2019, 2021). As Carey (2020) poignantly stated, Black boys are "scripted out of childhood and the innocence and freedom to play" (p. 731). As educators consider developmentally appropriate methods for enhancing healthy and 
secure attachments with young children while accounting for their social-emotional and developmental needs, Black boys are more likely to emerge from preschool as confident, nurtured, affirmed children eager to continue their educational journey.

Few studies have focused exclusively on the positive aspects of Black boys in the preschool context (Iruka et al., 2014). A qualitative study of Black preschool boys who attended a state-funded program in a large urban district revealed Black preschool boys experienced child well-being when their teacher valued them as individuals, shared in playful connections with the boys, allowed for a community-like classroom atmosphere, and had positive home school connections with the boys' families (Wint, 2020). Relatedly, Iruka et al. (2014) examined factors associated with high pre-academic skills for young Black boys in early childhood settings and found factors (e.g., family, preschool environment, individual characteristics for high-achieving Black boys) were significantly different than average and low achieving Black boys. Relevant research exploring the impact of contexts such as preschool and home environments on developmental outcomes for Black boys is warranted (Brown et al., 2013; Iruka et al., 2015). The policing of very young Black children begins as early as preschool (U.S. DOE Office for Civil Rights, 2014). Despite this reality, preschool-aged Black boys do thrive and achieve above expectations with the connected relational supports of teachers and their families (Iruka et al., 2014; Wint, 2020). The challenges experienced during this nurture-dependent phase of development signals a call for educators to improve methods and modes of communication across home and school contexts while providing age-appropriate foundational care for Black preschool boys.

\section{Elementary}

For boys who do not enroll in preschool or kindergarten, elementary school will be their first required school experience. Educational and psychological studies of Black boys during this developmental stage have focused on externalizing problems such as disruptive, oppositional, and aggressive behaviors (Brown et al., 2013; Wiesner et al., 2015). As they mature cognitively and physically and begin to develop their identities, Black boys become increasingly aware of their social location in society (Nelson et al., 2015; Noguera, 2003). Some Black boys contend with conflicting expectations of how to function within the communities in which they live, the stereotypical views society has of them, and the realities of who they are as individuals. Additionally, Black boys are often treated as older and less innocent than their same age White peers (Goff et al., 2014). At times, they are feared and misunderstood by those charged with supporting their educational needs during critical periods where they are most in need of nurturing, guidance, and support (Bryan, 2017; Rowley et al., 2014).

Teacher misperceptions of behavior may foster relational challenges and extend to negatively influence academic outcomes for Black boys in direct and indirect ways. A recent study found teachers were more likely to perceive Black kindergarten boys as having more external challenging behaviors than their same age peers from other racial and ethnic groups (Wood et al., 2017). Relational challenges may 
subsequently fuel misinformation about the value for education and the academic aptitude of Black boys. Black boys are often perceived as demonstrating indifference toward education and achievement (Howard, 2013). As a result, "teachers halt their efforts to nurture and promote achievement among Black males as early as the fourth grade" (Kunjufu, 1995 as cited by Harper \& Davis, 2012, p. 104). A lack of contextualized accounting for achievement opportunity gaps may also result in misconceptions about academic ability. While only 13\% of fourth-grade Black boys scored proficient in reading on the National Assessment of Educational Progress in comparison to $40 \%$ of fourth-grade White boys (Fields, 2014), testing disparities between Black and White boys were not solely due to socioeconomic status or academic ability. Rather, these differences reflect a cumulative effect of systemic challenges evident in many minoritized communities, such as inadequate educational resources and teaching as well as insufficient skill development and test preparation training (Harper \& Davis, 2012; Howard, 2013; Noguera, 2003). Without a contextualized view that incorporates the role of relationships and oppressive systems raw data often fails to capture the story of resilience behind the educational experiences of Black boys.

The misconception of educational value, academic potential, and ability further manifest as an insidious potential threat to achieving success for Black boys during both current and later years. Studies show those who are referred to gifted and talented programs are more likely to earn a bachelor's degree after completing high school (Rose, 2013). Black children are less likely to be referred for gifted and talented programs than White children, even when the criteria for acceptance are met (Grantham, 2013). As a result, exclusion from gifted and talented curricula during the elementary years may subsequently result in lost income potential for Black males in later years (Rose, 2013). As such, teachers' choices and support during elementary years may have long-term impact for Black boys as they mature.

As illustrated in the CLCIF (see Fig. 1), the life course perspective of Black boys through an intersectional lens, the principles of linked lives and agency may interact to create far-reaching implications for future academic success. Contrastingly, it is also important to consider how supportive relationship with consistent, caring, and supportive adults may provide positive and reparative experiences for Black boys who have had histories of unsteady and untrusting relationships (Sroufe et al., 2005).

\section{Harnessing Relational Strength}

Within the educational context, significant relationships (e.g., teacher-child, teacher-family) influence academic achievement (Dobbs \& Arnold, 2009; Howes \& Shivers, 2006). As detailed in the CLCIF, relational strength is an integral element that supports Black boys' growth and development. Educators who align their efforts with Black boys' lives develop meaningful relationships that support their academic efforts, interaction and communication skills, and developmental processes. Exploring the power and significance of the teacher-child relationship as a vehicle for improving social and academic success for Black boys and Black adolescent boys may serve as a valuable foundational tool for supporting their educational success. Research by Hamre and Pianta (2001) found the strength of the 
teacher-child relationship in kindergarten was a predictor of academic and behavioral outcomes from kindergarten through eighth grade. Empirical evidence suggests positive learning relationships are especially beneficial for teaching children who may struggle academically (Goings et al., 2015; Nelson, 2016). In addition, Black male students - relative to other racial groups - are more impacted by the support and reinforcement they receive from teachers (Noguera, 2003).

One tool used to explore the relational experiences of Black boys in education has been the relational teaching framework (Reichert \& Nelson, 2016). Relational teaching practice refers to the teacher's efforts to increase the engagement and learning of students by knowing and understanding who their students are as individuals and their position in the society (Reichert \& Hawley, 2014). This teaching practice suggests educators make efforts to connect and establish a shared perspective in their interactions with Black male students (Reichert \& Nelson, 2016). Relational teaching practice also requires teachers incorporate an intersectional lens and increase awareness of oppressive structures that exist for Black boys (Nelson, 2016). A relational posture necessitates teachers acknowledge rather than ignore the deficitbased narratives prevalent in society and align with Black males to counter those perspectives while maintaining high academic standards and expectations (Nelson, 2016; Wright \& Counsell, 2018). The practice of maintaining high academic standards for Black boys during the elementary years points toward the need to understand the perceptions teachers have of the value Black boys have for education. As noted by Brooms (2019), the expectations and practices of teachers toward Black boys were linked to the teachers' beliefs about the student's potential for success. As such, efforts to enhance educational opportunities for Black boys must start with Black boys being seen as capable, worthy, and engaging by those educators charged with supporting their academic futures.

As Black boys approach the finish line for elementary school, many have already tackled and maneuvered enormous obstacles solely due to their social identities. While resisting being pushed out and struggling to be perceived, supported, and treated as children, Black boys also struggle with being seen as academically capable, potentially gifted (Grantham, 2013), or relationally worthy of investment. The obstacles experienced during the first half of the developmental continuum illustrate how some Black boys may develop scars and wounds from their early educational years as they continue to strive towards their possibilities.

\section{Middle School and High School}

For Black boys this transition from childhood while being viewed as an adult, signals a profound reckoning of their social location as they are more likely to encounter discrimination than their same age peers (Berkel et al., 2009). Black males throughout the educational context are tasked with resisting the increased proliferation of unwarranted discipline referrals for subjective violations such as dress code or perceived disrespect. These infractions often result in increased time out of school, missed educational opportunities, and alienation from school administrators and peers (Cook et al., 2018; Skiba et al., 2014). Based on their school-related 
experiences during this transitional phase, Black adolescent boys may continue to develop distrust toward teachers (Bottiani et al., 2016; Okonofua et al., 2016). As such, Black boys and Black adolescent boys become increasingly aware of their status in society of simultaneously being both feared and oppressed-which places them at odds with educational success.

In addition to experiencing discrimination, developing Black adolescent boys are also fully engulfed in adolescence. As noted in the CLCIF they are simultaneously experiencing puberty and the related physical and emotional vulnerabilities. Some Black adolescent boys may lack academic confidence and question their abilities as they struggle to resist internalizing negative perceptions from others in society (Rogers et al., 2015; Thomas \& Stevenson, 2009). Black adolescent boys in middle and high school may also begin to feel a growing disconnect between the classroom environment and their lived experiences outside of school. This lack of congruence can hinder their learning and cause many Black males to view the educational arena as a place for "others" and possibly relinquish education as a viable tool for achieving success (Goings et al., 2015; Howard, 2013).

Perceived lack of care and support also present an additional challenge to academic success for Black adolescent boys (Bottiani et al., 2016; Nasir et al., 2018). Black adolescent high school students are often discouraged from attending college by their counselors or teachers and receive inadequate support to prepare for standardized examinations and college admission. Studies suggest Black high school students report perceptions of low expectations from their teachers as a challenge to their educational success (Harper \& Davis, 2012; Howard, 2013). This perception of experiencing a lack of care and support from educators is also evident among more vulnerable populations of Black males. For example, those who attended an alternative high school after withdrawing from a traditional high school report they believed their teachers did not care, had low educational expectations of them, and demonstrated unwillingness to assist the Black adolescent boys with academic tasks (Ransom, 2016).

The life course-intersectional perspective requires an accounting for the persistent role of oppression and disenfranchisement across multiple years in the educational context and highlights the cumulative impact of relational challenges and ongoing struggles. Contending with multiple and cumulative barriers to their educational success, the national rate of high school graduation for Black adolescent boys is still $59 \%$, compared to $80 \%$ for their White peers (Schott Foundation for Public Education, 2015). Efforts to counter the disparities during this phase requires considerations of prior challenges in addition to current developmental needs. As such, stakeholders must incorporate a layered yet contextual approach to first understanding and then addressing barriers to educational success during this critical transitional phase.

\section{Supporting Academic Goals}

Increasing expectations for Black adolescent boys facilitates the development of a positive academic identity and supports their self-efficacy and their ability to succeed. As Black adolescent boys transition into adolescence, high academic 
achievement may be perceived as less attainable. This change may be due in part to the spoken and unspoken messages they have received across their development regarding their competence (Howard, 2013; Taylor \& Graham, 2007). Guidance counselors and other school support staff are trusted to provide adequate assistance and help students identify their best options for achieving their potential and goals (Bryan et al., 2009; Ward, 2006).

A life course-intersectional lens requires educators and staff, such as school counselors, become increasingly aware of the challenges, pressures, and relational dynamics that exist among Black adolescent men during this phase. This awareness includes challenging negative stereotypes and fostering their ability to succeed. It may also require the knowledge and awareness Black adolescent boys at this stage may question the viability of achieving success within the educational context, given the related obstacles and challenges they have experienced prior to the point (e.g., see Howard, 2013). The vital role of support staff as change agents to advocate for Black adolescent boys requires collaboration with Black adolescent boys and their families to ensure the academic and career goals are achieved upon completing high school and transitioning to college (Holcomb-McCoy, 2010; Stamato et al., 2018). This collaboration must also be nested within the context of an authentic relationship. Experiencing trust and care within his immediate context has been associated with positive educational outcomes for Black adolescent boys and can be empowering (Brooms, 2019; Goings et al., 2015; Nasir et al., 2018). As such, Leonard (2011) outlined the combined effort of school, family, and the community through the concept of the "community-school" as a method to address structural and systemic issues and barriers for Black adolescent boys.

\section{Implications}

A comprehensive exploration of the educational journey of Black boys starting at preschool and culminating in the high school highlights the struggle, disenfranchisement, and oppressive structures that persist across development. More significantly, the culminating losses, traumas, and injustices fueled by racial inequality and oppression are rarely acknowledged or addressed in ways that leave Black boys resolved or complete in their process of emotional healing or repair (CopelandLinder et al., 2010; Trent et al., 2019).

Educators and practitioners are urged to embrace a life course-intersectional framework as a step toward increasing their understanding of the educational experiences Black boys and Black adolescent boys encounter across their educational trajectory. In the educational context, individuals in positions of power (e.g., teachers, administrators) possess the ability to establish inclusionary or exclusionary boundaries and determine who is entitled to certain resources (e.g., programs, interventions). The interlinking grids of differential positions and identities (e.g., class, race, ethnicity, gender, sexuality, ability, stage of the life cycle) established a power imbalance that contributes to the deficit lens placed on Black children and their families (Yuval-Davis, 2006). As such, leveraging power and resources may increase support for Black boys. 
Importantly, this discussion outlines strengths-based approaches for implementation across various sectors (i.e., communities, schools, and research agendas). These approaches have the potential to change the deficit view of Black boys and Black adolescent boys by illuminating their strengths through the promotion of protective factors. The CLCIF provides implications for policy makers and educators to implement initiatives that acknowledge the inequities Black males are exposed from birth to adulthood. As previously detailed and discussed, there are protective factors that can be implemented within the school, community, and family sectors across each developmental stage to allow Black boys and Black adolescent boys to realize their possibilities.

\section{Adjusting the Research Agenda}

To develop quality programming and evaluate the success of such programs, researchers must understand how to effectively measure outcomes and identify effective approaches for supporting Black boys and Black adolescent boys at each stage of development. The importance of timing and strategic implementation of protective factors should also be further explored. This new knowledge requires a shift in the kind of data gathered as well as the data collection process. Encouraging schools in urban under-resourced communities to collect data on engagement, high achievement, and retention rates during the preschool, elementary, middle, and high school years for Black boys and Black adolescent boys, may provide critical knowledge for establishing quality programming and identifying crucial gaps in education. Given neighborhood factors (e.g., poverty level, employment rates, crime rates) can have a profound effect on education in under-resourced communities (Baker, 2015; Iruka et al., 2015), routinely engaging in community-based participatory research can allow researchers to establish practical and holistic approaches to understanding Black boys and Black adolescent boys. One example of community-based strategies may include immersion in the communities that support Black boys and Black adolescent boys to understand their day-to-day experiences. Engaging Black males and their families in focus group interviews, semi-structured individual interviews, and other qualitative methods gives voice to the unique experiences and resources utilized to overcome challenges they face on the road to educational success (Allen \& White-Smith, 2018; Brooms, 2019; Nasir et al., 2018). Efforts to understand the lived realities of Black males requires the research community adjust power dynamics and foster collaboration and cocreation of knowledge with Black boys and Black adolescent boys.

More research is required to question and highlight instances across the educational continuum where Black boys and Black adolescent boys are flourishing, despite the barriers (Gaylord-Harden et al., 2018; Howard et al., 2016; Iruka et al., 2014). A strengths-based perspective requires researchers to ask questions such as: What is working well? At what stage of development? In what context? and For Whom? This shift may increase our understanding of strengths, protective factors, and solutions utilized by Black boys and men towards overcoming challenges to their educational success. Relatedly, while there are discipline disparity rates for Black boys, more questions are warranted regarding the protective factors which influence $80 \%$ of Black boys from elementary to high school who 
have not been suspended (U.S. DOE Office for Civil Rights, 2014). These questions must be asked early in the educational journey and continue throughout the life course as a means of accounting for evolving individuals, relationships, systems, and contexts. An accurate understanding of strengths requires researchers to incorporate considerations for the range of experiences, settings, and relationships Black boys and Black adolescent boys encounter. Uncovering elements that foster successful outcomes rather than solely examining problematic elements, may provide crucial knowledge for identifying resources and targeting critical supports. Framing these efforts within an intersectional framework can contribute to understanding the nuances of how systems of power work to influence schooling experiences for Black boys and Black adolescent boys (Nelson et al., 2015; Rogers et al., 2015).

\section{Conclusion}

Understanding factors that promote resilience and positive development for Black boys and Black adolescent boys are vital as they are certain to face a myriad of obstacles across their lifespan both in and out of the educational context. Given schools are social systems, educators, families, and policymakers must understand how the cumulative realities of being educated in oppressive systems and encountering racist ideologies are often unconsciously internalized by Black boys, their non-Black peers, as well as those charged with supporting their educational development (Allen, 2015; Nasir et al., 2018). The communities and schools in which Black boys and Black adolescent boys are developing must be equipped to contextualize their experiences, nurture, and affirm their potential as they flourish. The use of life course and intersectionality theories to analyze the development of Black boys points toward an important shift in how educational stakeholders may provide support for a consistently marginalized population. Continuing discourses which underscore a contextual and stage-related perspective for supporting Black males while simultaneously focusing on their strengths, skills, and resilience may provide innovative new directions for educational research and the possibilities of Black boys in education.

\section{Declaration}

Conflict of interest All authors declare that they have no known conflict to disclose.

\section{References}

Allen, Q. (2015). Race, culture, and agency: Examining the ideologies and practices of U.S. teachers of Black male students. Teaching and Teacher Education, 47, 71-81. https://doi.org/10.1016/j. tate.2014.12.010 
Allen, Q., \& White-Smith, K. (2018). "That's why I say stay in school”: Black mothers' parental involvement, cultural wealth, and exclusion in their son's schooling. Urban Education, 53(3), 409-435. https://doi.org/10.1177/0042085917714516

Baker, C. E. (2015). Does parent involvement and neighborhood quality matter for African American boys' kindergarten mathematics achievement? Early Education \& Development, 26(3), 342355. https://doi.org/10.1080/10409289.2015.968238

Bates, L. A., \& Glick, J. E. (2013). Does it matter if teachers and schools match the student? Racial and ethnic disparities in problem behaviors. Social Science Research, 42(5), 1180-1190. https:// doi.org/10.1016/j.ssresearch.2013.04.005

Berkel, C., Murry, V. M., Hurt, T. R., Chen, Y.-F., Brody, G. H., Simons, R. L., Cutrona, C., \& Gibbons, F. X. (2009). It takes a village: Protecting rural African American youth in the context of racism. Journal of Youth and Adolescence, 38(2), 175-188.

Bottiani, J. H., Bradshaw, C. P., \& Mendelson, T. (2016). Inequality in Black and White high school students' perceptions of school support: An examination of race in context. Journal of Youth \& Adolescence, 45(6), 1176-1191. https://doi.org/10.1007/s10964-015-0411-0

Brenner, A. D. (2011). The transition from high school: Current knowledge, future directions. Educational Psychology Review, 23(3), 299-328. https://doi.org/10.1007/s10648-011-9152-0

Bronfenbrenner, U., \& Morris, P. A. (2006). The bioecological model of human development. In R. M. Lerner \& W. Damon (Eds.), Handbook of child psychology: Vol. 1.Theoretical models of human development (6th ed., pp. 793-828). New York: Wiley.

Brooms, D. R. (2017). Being Black, being male on campus: Understanding and confronting Black male collegiate experiences. New York: SUNY Press.

Brooms, D. R. (2019). "I was just trying to make it”: Urban Black males' sense of belonging, schooling experiences, and academic success. Urban Education, 54(6), 804-830. https://doi.org/10. $1177 / 0042085916648743$

Brown, J., Barbarin, O., \& Scott, K. (2013). Socioemotional trajectories in Black boys between kindergarten and the fifth grade: The role of cognitive skills and family in promoting resiliency: Development of boys of color. American Journal of Orthopsychiatry, 83(2), 176-184. https:// doi.org/10.1111/ajop.12027

Brown, T. L., Linver, M. R., Evans, M., \& Degennaro, D. (2008). African American parents' racial and ethnic socialization and adolescent academic grades: Teasing out the role of gender. Journal of Youth and Adolescence, 38(2), 214-227. https://doi.org/10.1007/s10964-008-9362-z

Bryan, N. (2017). White teacher's role in sustaining the school-to-prison pipeline: Recommendations for teacher education. Urban Review, 49(2), 326-345. https://doi.org/10.1007/ s11256-017-0403-3

Bryan, N. (2019). "Playing with or like the girls": Advancing the performance of "multiple masculinities in Black boys" childhood play' in U.S. early childhood classrooms. Gender and Education, 31(3), 309-326. https://doi.org/10.1080/09540253.2018.1447091

Bryan, N. (2021). Remembering Tamir Rice and other Black boy victims: Imagining Black playCrit literacies inside and outside urban literacy education. Urban Education, 56(5), 744-771. https:// doi.org/10.1177/0042085920902250

Bryan, J., Holcomb-McCoy, C., Moore-Thomas, C., \& Day-Vines, N. L. (2009). Who sees the school counselor for college information? A National Study. Professional School Counseling, 12(4), 280291. https://doi.org/10.1177/2156759X0901200401

Carey, R. L. (2020). Making Black boys and young men matter: Radical relationships, future oriented imaginaries and other evolving insights for educational research and practice. International Journal of Qualitative Studies in Education, 33(7), 729-744. https://doi.org/10.1080/09518398.2020. 1753255

Center on the Developing Child at Harvard University (CDCHU). (2015). Supportive relationships and active skill-building strengthen the foundations of resilience. https://46y5eh11fhgw $3 \mathrm{ve} 3 \mathrm{ytpwxt} 9 \mathrm{r}-$ wpengine.netdna-ssl.com/wp-content/uploads/2015/05/The-Science-of-Resilience2.pdf

Collins, P. H. (2000). Gender, black feminism, and black political economy. The Annals of the American Academy of Political and Social Science, 568(1), 41-53. https://doi.org/10.1177/0002716200 56800105

Copeland-Linder, N., Lambert, S. F., Chen, Y., \& Ialongo, N. S. (2010). Contextual stress and health risk behaviors among African American adolescents. Journal of Youth and Adolescence, 40(2), 158-173. https://doi.org/10.1007/s10964-010-9520-y 
Cook, C. B., Duong, M. T., McIntosh, K., Fiat, A. E., Pullmann, M. D., \& McGinnis, J. (2018). Addressing discipline disparities for Black male students: Linking malleable root causes to feasible and effective practices. School Psychology Review, 47(2), 135-152. https://doi.org/10.17105/spr-20170026.v47-2

Cooke, T. (2008). Full, full, full of love. Somerville: Candlewick.

Crenshaw, K. W. (1989). Demarginalizing the Intersection of Race and Sex: A Black Feminist Critique of Antidiscrimination Doctrine. University of Chicago Legal Forum (pp. 139-168). http://chicagounb ound.uchicago.edu/uclf/vol1989/iss1/8

Crenshaw, K. (1991). Mapping the margins: Intersectionality, identity politics, and violence against women of color. Stanford Law Review, 43(6), 1241-1299. https://doi.org/10.2307/1229039

Curry, T. (2017). The man-not: Race, class, genre, and the dilemmas of Black manhood. Temple University Press.

Davis, J. E. (2003). Early schooling and academic achievement of African American males. Urban Education, 38(5), 515-537. https://doi.org/10.1177/0042085903256220

Delgado, R. (2005). Critical race theory: An introduction. New York: NYU Press.

Dobbs, J., \& Arnold, D. (2009). Relationship between preschool teacher's reports of children's behavior and their behavior towards these children. School Psychology Quarterly, 24(2), 95-105. https://doi. org/10.1037/a0016157

Downer, J. T., Goble, P., Myers, S. S., \& Pianta, R. C. (2016). Teacher-child racial/ethnic match within pre-kindergarten classrooms and children's early school adjustment. Early Childhood Research Quarterly, 37, 26-38. https://doi.org/10.1016/j.ecresq.2016.02.007

Dreyer, B. P., Trent, M., Anderson, A. T., Askew, G. L., Boyd, R., Coker, T. R., \& Stein, F. (2020). The death of George Floyd: bending the arc of history toward justice for generations of children. Pediatrics. https://doi.org/10.1542/peds.2020-009639

Dumas, M. J., \& Nelson, D. J. (2016). (Re)imagining Black boyhood: Toward a critical framework for educational research. Harvard Educational Review, 86(1), 27-47. https://doi.org/10.17763/00178055.86.1.27

Edwards, A., \& Few-Demo, A. (2016). African American maternal power and the racial socialization of preschool children. Sex Roles, 75(1-2), 56-70. https://doi.org/10.1007/s11199-016-0633-y

Elder, G. H., Jr. (1998). The life course and human development. In W. Damon \& R. M. Lerner (Eds.), Handbook of child psychology (Vol. 1, pp. 939-991). New York: Wiley.

Elder, G. H., Jr., \& Shanahan, M. J. (2006). The life course and human development. In R. M. Lerner \& W. Damon (Eds.), Handbook of child psychology: Theoretical models of human development (pp. 665-715). New York: Wiley.

Fergus, E., Noguera, P., \& Martin, M. (2014). Schooling for resilience: Improving the life trajectory of Black and Latino boys. Harvard Education Press.

Fields, R. (2014). Towards the National Assessment of Educational Progress (NAEP) as an indicator of academic preparedness for college and job training. National Assessment Governing Board. Retrieved September 8, 2018 from https://files.eric.ed.gov/fulltext/ED582999.pdf

Garcia Coll, C. T., Lamberty, G., Jenkins, R., McAdoo, H. P., Crnic, K., Wasik, B. H., \& Vazquez Garcia, H. (1996). An integrative model for the study of developmental competencies in minority children. Child Development, 67(5), 1891-1914. https://doi.org/10.1111/j.1467-8624.1996.tb01834.x

Gaylord-Harden, N. K., Barbarin, O., Tolan, P. H., \& McBride Murry, V. M. (2018). Understanding development of African American boys and young men: Moving from risks to positive youth development. American Psychologist, 73(6), 753-767. https://doi.org/10.1037/amp0000300

Gilliam, W. S., Maupin, A. N., Reyes, C. R., Accavitti, M., \& Shic, F. (2016). Do early educators' implicit biases regarding sex and race relate to behavior expectations and recommendations of preschool expulsions and suspensions? Yale Child Study Center. Retrieved May 11, 2017 from https://medicine.yale.edu/childstudy/zigler/publications/Preschool\%20Implicit\%20Bias\%20Pol icy\%20Brief_final_9_26_276766_5379_v1.pdf

Goings, R. B., Smith, A., Harris, D., Wilson, T., \& Lancaster, D. (2015). Countering the narrative: A layered perspective on supporting Black males in education. Penn GSE Perspectives on Urban Education, 12(1), 54-63.

Goff, P. A., Jackson, M. C., Di Leone, B. A. L., Culotta, C. M., \& DiTomasso, N. A. (2014). The essence of innocence: Consequences of dehumanizing Black children. Journal of Personality and Social Psychology, 106(4), 526-545. https://doi.org/10.1037/a003566

Grantham, T. C. (2013). Creativity and equity: The legacy of E. Paul Torrance as an upstander for gifted Black males. Urban Review, 45, 518-538. https://doi.org/10.1007/s11256-013-0257-2 
Grey, T. G. (2018). Repping' and risin' above: Exploring communities of possibility that affirm the college-going aspirations of Black youth. Urban Education,. https://doi.org/10.1177/0042085918 804020

Hamre, B. K., \& Pianta, R. C. (2001). Early teacher-child relationships and the trajectory of children's school outcomes through eighth grade. Child Development, 72(2), 625-638. https://doi.org/10. $1111 / 1467-8624.00301$

Harper, F. D., Terry, L. M., \& Twiggs, R. (2009). Counseling strategies with Black boys and Black men: Implications for policy. Journal of Negro Education, 78(3), 216-232.

Harper, S. R. (2010). An anti-deficit framework for research on students of color in STEM. New Directions for Institutional Research, 148, 63-74. https://doi.org/10.1002/ir.362

Harper, S. R., \& Davis, III C. H.. (2012). They (don't) care about education: A counternarrative on Black male students' responses to inequitable schooling. Educational Foundations, 26(1), 103-120.

Harrison, V. (2019). Little legends: Exceptional men in Black history. Little, Brown Book for Young Readers.

Hines, E. M., \& Holcomb-McCoy, C. (2013). Parental characteristics, ecological factors, and the academic achievement of African American males. Journal of Counseling \& Development, 91(1), 68-77. https://doi.org/10.1002/j.1556-6676.2013.00073.x

Holcomb-McCoy, C. (2010). Involving low-income parents and parents of color in college readiness activities: An exploratory study. Professional School Counseling, 11(1), 115-124. https://doi.org/ 10.1177/2156759X1001400111

Howard, L. C., Rose, J. C., \& Barbarin, O. A. (2013). Raising African American boys: An exploration of gender and racial socialization practices. American Journal of Orthopsychiatry, 83(2-3), 218-230. https://doi.org/10.1111/ajop.12031

Howard, T. C. (2001). Telling their side of the story: African American students' perceptions of culturally relevant reaching. Urban Review, 33(2), 131-149. https://doi.org/10.1023/A:1010393224120

Howard, T. C. (2013). How does it feel to be a problem? Black male students, schools, and learning in enhancing the knowledge base to disrupt deficit frameworks. Review of Research in Education, 37(1), 54-86. https://doi.org/10.3102/0091732X12462985

Howard, T. C., Douglas, T. O., \& Warren, C. A. (2016). "What works": Recommendations on improving academic experiences and outcomes for Black males. Teachers College Record, 118(6), 1-10.

Howes, C., \& Shivers, E. (2006). New child-caregiver attachment relationships: Entering child- care when the caregiver is and is not an ethnic match. Social Development, 15(4), 574-590. https://doi. org/10.1111/j.1467-9507.2006.00358.x

Iruka, I. U., Curenton, S. M., Durden, T. R., \& Escayg, K. (2020). Don't look away: Embracing anti-bias classrooms. New York: Gryphon House.

Iruka, I. U., Curenton, S. M., \& Gardner, S. (2015). How changes in home and neighborhood environment factors are related to change in Black children's academic and social development from kindergarten to third grade. Journal of Negro Education, 84(3), 282-297. https://doi.org/10.7709/ jnegroeducation.84.3.0282

Iruka, I. U., Winn, D. C., \& Harradine, C. (2014). High achieving African American boys: Factors that contribute to their excellence in the early years. In J. L. Moore III \& C. W. Lewis (Eds.), African American male students in prek-12 schools: Informing research, policy, and practice (pp. 27-59). Emerald Group. https://doi.org/10.1108/S2051-231720140000002020

Jackson, I., Sealey-Ruiz, Y., \& Watson, W. (2014). Reciprocal love: Mentoring Black and Latino males through an ethic of care. Journal of Urban Education, 49(4), 394-417. https://doi.org/10.1177/ 0042085913519336

Jenkins, T. S. (2006). Mr. Nigger: The challenges of educating Black males within American society. Journal of Black Studies, 37(1), 127-155. https://doi.org/10.1177/0021934704273931

Johnson, M. K., Crosnoe, R., \& Elder, G. H., Jr. (2001). Students' attachment and academic engagement: The role of race and ethnicity. Sociology of Education, 74(4), 318-340. https://doi.org/10.2307/ 2673138

Kunjufu, J. (1995). Countering the conspiracy to destroy Black boys series. African American Images.

Leonard, J. (2011). Using Bronfenbrenner's ecological theory to understand community partnerships: A historical case study of one urban high school. Urban Education, 46(5), 987-1010. https://doi.org/ $10.1177 / 0042085911400337$

Lucas, Y. (2018). Support structures: Challenges and potential solutions toward persistence in earning a baccalaureate degree for Black male students attending predominantly White institutions. Journal of Business Diversity, 18(1), 68-78. https://doi.org/10.33423/jbd.v18i1.519 
Mandara, J. (2006). The impact of family functioning on African American males' academic achievement: A review and clarification of the empirical literature. Teachers College Record, 108(2), 206223. https://doi.org/10.1111/j.1467-9620.2006.00648.x

Martin, A. J. (2007). Examining a multidimensional model of student motivation and engagement using a construct validation approach. British Journal of Educational Psychology, 77(2), 413-440. https:// doi.org/10.1348/000709906X118036

McCready, L. (2010). Making space for diverse masculinities: Difference, intersectionality, and engagement in an urban high school. New York: Peter Lang.

Morhard, R. H. (2013). Wired to move: Facts and strategies for nurturing boys in an early childhood setting. New York: Gryphon House.

Mutua, A. D. (2006). Theorizing progressive Black masculinities. In A. D. Mutua (Ed.), Progressive Black masculinities (pp. 3-42). Routledge.

Nasir, N. S., Givens, J. R., \& Chatmon, C. P. (2018). "We dare say love": Supporting achievement in the educational life of Black boys. New York: Teachers College Press.

National Black Child Development Institute. (2015). Being Black is not a risk factor: A strength-based look at the state of the Black child. Retrieved October 27, 2017 from https://www.nbcdi.org/sites/ default/files/resource-files/Being\%20Black\%20Is\%20Not\%20a\%20Risk\%20Factor_0.pdf

National Institute for Early Education Research (NIEER). (2015). State of preschool yearbooks. Retrieved 2016 from http://nieer.org/state-preschool-yearbooks/the-state-of-preschool-2015

Nelson, J. D. (2016). Relational teaching with Black boys: Strategies for learning at a single-sex middle school for boys of color in New York City. Teachers College Record, 118(6), 1-30.

Nelson, J. D., Stahl, G., \& Wallace, D. (2015). Race, class, and gender in boys' education: Repositioning intersectionality theory. Culture, Society, \& Masculinities, 7(2), 171-187. https://doi.org/10.3149/ cms.0702.17110.3149/csm.0702.171

Noguera, P. A. (2003). The trouble with Black boys: The role and influence of environmental and cultural factors on the academic performance of African American males. Urban Education, 38(4), 431-459. https://doi.org/10.1177/0042085903038004005

Okonofua, J. A., Walton, G. M., \& Eberhardt, J. L. (2016). A vicious cycle: A social-psychological account of extreme racial disparities in school discipline. Association for Psychological Science, 11(3), 381-398. https://doi.org/10.1177/1745691616635592

Patton, L. D., Bridges, B. K., \& Flowers, L. A. (2011). Effects of Greek affiliation on African American students' engagement differences by college racial composition. College Student Affairs Journal, 29(2), 113-123.

Pungello, E. P., Kainz, K., Burchinal, M., Wasik, B. H., Sparling, J. J., Ramey, C. T., \& Campbell, F. A. (2010). Early educational intervention, early cumulative risk, and the early home environment as predictors of young adult outcomes within a high-risk sample. Child Development, 81(1), 410426. https://doi.org/10.1111/j.1467-8624.2009.01403.x

Ransom, J. C. (2016). Caring for Black males in schools: An ethnographic exploration of educational experiences of Black males in a GED program. Urban Education Research and Policy Annuals, 4(1), 91-98.

Rashid, H. M. (2009). From brilliant baby to child placed at risk: The perilous path of African American boys in early childhood education. Journal of Negro Education, 78(3), 347-358.

Reichert, M., \& Hawley, R. (2014). I can learn from you: Boys as relational learners. Harvard: Harvard Education Press.

Reichert, M., \& Nelson, J. (2016). Relational teaching with primary and junior boys: What works for teachers, students, and parents. International Boys' Schools Coalition. https://www.theibsc.org/ teaching-learning/global-research/reports

Rogers, L. O., Scott, M. A., \& Way, N. (2015). Racial and gender identity among Black adolescent males: An intersectionality perspective. Child Development, 86(2), 407-424. https://doi.org/10.1111/cdev. 12303

Rose, V. C. (2013). School context, precollege educational opportunities, and college degree attainment among high-achieving black males. Urban Review, 45(4), 472-489. https://doi.org/10.1007/ s11256-013-0258-1

Rowley, S. J., Ross, L., Lozada, F. T., Williams, A., Gale, A., \& Kurtz-Costes, B. (2014). Framing Black boys: Parent, teacher, and student narratives of the academic lives of Black boys. Advances in Child Development \& Behavior, 47, 301-332. https://doi.org/10.1016/bs.acdb.2014.05.003

Schott Foundation for Public Education. (2015). Yes we can: The 2015 state report on public education for Black males. Retrieved February 13, 2015 from http://www.schottfoundation.org 
Skiba, R. J., Arredondo, M. I., \& Williams, N. T. (2014). More than a metaphor: The contribution of exclusionary discipline to a school-to-prison pipeline. Equity \& Excellence in Education, 47(4), 546-564. https://doi.org/10.1080/10665684.2014.958965

Sroufe, L. A., Egeland, B., Carlson, E., \& Collins, W. A. (2005). Placing early attachment experiences in developmental context. In K. E. Grossmann, K. Grossmann, \& E. Waters (Eds.), The power of longitudinal attachment research: From infancy and childhood to adulthood (pp. 48-70). Guilford.

Stamato, L., Johnson, S. L., \& Cheng, T. L. (2018). "I used to be wild": Adolescent perspectives on the influence of family, peers, school, and neighborhood on positive behavioral transition. Youth \& Society, 50(1), 49-74. https://doi.org/10.1177/0044118X15586146

Swanson, D. P., Cunningham, M., \& Spencer, M. B. (2003). Black males' structural conditions, achievement patterns, normative needs, and opportunities. Urban Education, 38(5), 608-633. https://doi. org/10.1177/0042085903256218

Taylor, A. Z., \& Graham, S. (2007). An examination of the relationship between achievement values and perceptions of barriers among low-SES African American and Latino students. Journal of Educational Psychology, 99(1), 52-64. https://doi.org/10.1037/0022-0663.99.1.52

Thomas, D. E., \& Stevenson, H. (2009). Gender risks and education: The particular classroom challenges for urban low-income African American boys. Review of Research in Education, 33(1), 160-180. https://doi.org/10.3102/0091732X08327164

Toldson, I. A., Harrison, M. G., Perine, R., Carreiro, P., \& Caldwell, L. D. (2006). Assessing the impact of family process on rural African American adolescent competence and behavior using latent growth curve analysis. Journal of Negro Education, 75(3), 430-442.

Toliver, S. R. (2018). Unlocking the cage: Empowering literacy representations in Netflix's Luke Cage series. Journal of Adolescent \& Adult Literacy, 61(6), 621-630. https://doi.org/10.1002/jaal.721

Trent, M., Dooley, D. G., \& Dougé, J. (2019). The impact of racism on child and adolescent health. Pediatrics, 144(2), e20191765. https://doi.org/10.1542/peds.2019-1765

U.S. Department of Education Office for Civil Rights. (2014). Civil rights data collection data snapshot: Early childhood education. Retrieved March 19, 2017 from https://ocrdata.ed.gov/Downloads/ CRDC-Early-Childhood-Education-Snapshot.pdf

Veenstra, G. (2011). Race, gender, class, and sexual orientation: Intersecting axes of inequality and selfrated health in Canada. International Journal for Equity in Health, 10(3), 1-11. https://doi.org/10. 1186/1475-9276-10-3

Ward, N. L. (2006). Improving equity and access for low-income and minority youth into institutions of higher education. Urban Education, 41(1), 50-70. https://doi.org/10.1177/0042085905282253

Wood, D. A., Kurtz-Costes, B., \& Copping, K. E. (2011). Gender differences in motivational pathways to college for African American youth: A test of expectancy-value theory. Developmental Psychology, 47(4), 961-968. https://doi.org/10.1037/a0023745

Wood, J. L., Essien, I., \& Blevins, D. (2017). Black males in kindergarten: The effect of social skills on close and conflictual relationships with teachers. Journal of African American Males in Education, $8(2), 30-50$.

Wiesner, M., Elliott, M. N., McLaughlin, K. A., Banspach, S. W., Tortolero, S., \& Schuster, M. A. (2015). Common versus specific correlates of fifth-grade conduct disorder and oppositional defiant disorder symptoms: Comparison of three racial/ethnic groups. Journal of Abnormal Child Psychology, 43(5), 985-998. https://doi.org/10.1007/s10802-014-9955-9

Wint, K. M. (2020). The beginning: Exploring educational experiences of Black boys in state-funded preschools [Unpublished doctoral dissertation]. Montclair State University.

Wright, B. L., \& Counsell, S. L. (2018). The brilliance of Black boys: Cultivating school success in the early grades. New York: Teachers College Press.

Wright, C., Maylor, U., \& Becker, S. (2016). Young Black males: Resilience and the use of capital to transform school "failure." Critical Studies in Education, 57(1), 21-34. https://doi.org/10.1080/ 17508487.2016 .1117005

Yuval-Davis, N. (2006). Intersectionality and feminist politics. European Journal of Women's Studies, 13(3), 193-209. https://doi.org/10.1177/1350506806065752

Publisher's Note Springer Nature remains neutral with regard to jurisdictional claims in published maps and institutional affiliations. 